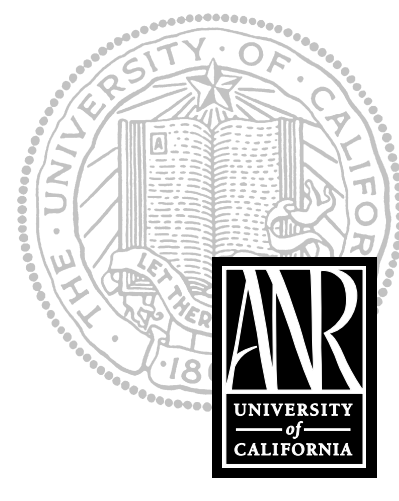

UNIVERSITY OF CALIFORNIA

Agriculture and Natural Resources

http://anrcatalog.ucdavis.edu

\title{
Spinach Production: Sample Costs and Profitability Analysis
}

\section{Based on 1999 Data Collected in Ventura County, California}

Etaferahu Takele, Area Farm Advisor, Agricultural Economics and Farm Management,
UC Cooperative Extension in Southern California.

The author wishes to express her appreciation to the University of California, Division of Agriculture and Natural Resources, Thelma Hansen Trust for funding this project. She also expresses her appreciation to those growers and other cooperators who provided data and review in the development of this study.

This study presents sample costs of production for fresh market spinach developed in Ventura County, in 1999, but the methodology we used to analyze costs, profits, and investments can easily be modified to address individual situations in production areas throughout California. Tables 1 and 2 include a "Your cost" column where growers can enter their own costs for comparison with ours. Also note that because of rounding, the totals given in tables 1 through 6 may differ slightly from the sums of their constituent numbers.

We based our study on certain assumptions that we developed from production practice and cost information gathered from growers and agricultural institutions in the area. This is one of a series of six reports on vegetable crop production that are based on Ventura County data.

As a grower or other agriculture professional, you can benefit from this report in many ways. It can help you make production decisions, determine potential returns, prepare budgets, evaluate production loans, and analyze policies.

A discussion of the assumptions and calculation methods we used in this study is provided in the text. Cultural practice and cost data are presented in detail in six tables:

Table 1. Costs per acre to produce spinach

Table 2. Costs and returns per acre to produce spinach

Table 3. Monthly cash costs per acre to produce spinach

Table 4. Range analyses of spinach production costs and returns

Part A. Costs per acre and per carton at varying yields

Part B. Returns per acre above cash operating costs

Part C. Returns per acre above all cash costs (gross margin)

Part D. Returns per acre above total costs (returns to management)

Table 5. Farm equipment and investment values and annual costs

Table 6. Farm equipment actual hours use and hourly costs 


\section{STUDY ASSUMPTIONS}

This report is based on a 1,300-acre vegetable farm, the average size of farm for the growers we interviewed. Most land used for vegetable crops in Ventura County produces two or more crops a year. Each crop is planted and harvested several times a year, so planting, harvesting, and selling of vegetable crops are year-round activities for growers, farm workers, and sellers.

We calculated our costs assuming that at least two crops are produced on each acre, resulting in a total of 2,600 acres of farmed land per year. For our study, the crops grown on the farm include broccoli, bell pepper, celery, spinach, loose-leaf lettuce, and cilantro (we have issued a report similar to this one for each of these crops). This crop mix is not present, of course, on every farm in Ventura County, but several farms in our interview pool did produce all six crops.

The growing period for each crop varies depending on time of planting. Consequently, production costs-particularly for irrigation, disease, and pest management, as well as overhead expenses-would be expected to vary. We based our study on an average growth period of minimum and maximum days. Prices used for materials, equipment, contract services, and labor wages (unless otherwise specified) are for the year 1999 .

\section{CULTURAL PRACTICES AND PRODUCTION INPUTS}

Land preparation. Different types of fields and management preferences require different types of land preparation. Most growers in our interview pool performed several operations including multiple discing (five times in this study), ripping the soil (maybe twice) to break up any underlying compacted soil, plowing, leveling using a triplane, chiseling, furrowing, listing, and shaping beds. Preplant fertilizer is applied together with the listing before the ground is shaped and rolled into beds.

Stand establishment. Spinach is grown primarily in the southern desert valleys, the south coast, the central coast, and the central San Joaquin Valley. The primary varieties produced in Ventura County are St. Helens, Rushmore, and Springfield, all of which require similar cultural, harvesting, and marketing techniques.

Seeding rates vary depending on spacing. For this study, we assumed a rate of approximately 1 million seeds per acre. Seeds are planted six rows to a bed with bed centers 40 inches apart and seeds 1 inch apart within a row at a depth of $1 / 2$ inch.

Weed management. Many growers in Ventura County use cultivation and preemergence herbicides to control a wide range of grass and broadleaf weeds. Spinach is quite vulnerable to weed infestations during the seedling stage. Weeds common to spinach include stinging nettle (Urtica urens), annual bluegrass (Poa annua), sowthistle (Sonchus oleraceus), and prickly lettuce (Latuca serriola) as well as others not mentioned in this text.

Fertilization. As mentioned previously, preplant fertilizer of nitrogen $(\mathrm{N})$ and phosphorous is in most cases applied together with listing before the ground is shaped and rolled into beds.

Fertilizer applications during the growth period are mostly $\mathrm{N}$ and are applied via the furrow irrigation system. The amount and type of fertilizer we included in this study are based on an average of what most growers applied.

Irrigation. During germination, irrigation is applied via a sprinkler system. Growers can purchase or rent sprinkler irrigation systems. We calculated costs for this study based on ownership of an existing sprinkler irrigation system. 
Growers can irrigate a field one portion at a time, moving pumps, pipes, and fittings manually from field to field. For this study, we assumed that sufficient pumps, pipes, and fittings are available to irrigate 430 acres at a time. Pipes are transported using a trailer and a tractor. Spreading the pipes takes 90 minutes of manual labor per acre. Removing pipes takes about the same amount of time.

After seedlings have broken through the soil, growers switch the irrigation to a furrow system. Irrigation labor for inspection of the system and maintenance is estimated at about 30 minutes per acre per irrigation for sprinklers and about 20 minutes per acre per irrigation for furrow irrigation.

Energy use for pumping includes both diesel fuel and electric power, depending on the irrigation system. The amount of diesel and electricity consumption depends on pump horsepower (HP). In our study we used a 100 HP diesel pump and a 70 HP electric pump. We estimated that 21 gallons of diesel and 252 kilowatts (KW) of electricity would be needed per acre during the production period of spinach.

The cost of water to irrigate crops varies greatly from region to region in Ventura County, and also depending on whether district or well water is used. The farm in this study is in the Oxnard plains, where growers use both well and district water. We calculated the water cost at $\$ 82$ per acre-foot. This rate is a weighted average for pumping costs and district charges assuming that one-third of the water comes from wells and the remaining two-thirds from districts. Irrigation in spinach crop production commonly runs about 12 acre-inches of water.

Pest and disease management. Most of the insects that can affect spinach production are leafminers, and most of them can be treated at the larval stage. Growers usually rotate insecticides in order to slow potential pest resistance, depending on the region. Written recommendations from State of California-licensed pest control advisors are required for pesticide use. For information and pesticide use permits, contact your local county Agricultural Commissioner's office. You can also find pest management information from the University of California on the UC Statewide Integrated Pest Management Project website, http://www.ipm.ucdavis.edu.

A number of diseases may infect spinach during any phase of growth. In Ventura County, the most common diseases affecting spinach are downy mildew, cucumber mosaic virus (CMV), and beet western yellows virus (BWYV). This study assumes the application of a preventative fungicide treatment.

\section{HARVEST AND SELL}

The spinach crop is field-packed into cartons. A carton typically contains about 14 to 18 bunches of spinach and has an overall weight of about 20 pounds. A bunch contains 8 to 12 plants. After the spinach crop is packed, it is quickly transported to a storage facility where it is cooled and palletized at scientifically recommended temperatures.

Harvesting costs in this study include the cost of cartons, picking and packing, loading, and hauling to the nearest cooling facility. We estimated a cost of $\$ 1.20$ for the carton itself, $\$ 1.00$ per carton for picking and packing, and $\$ 0.65$ per carton for loading and hauling. Selling costs are estimated at $\$ 0.50$ per carton. We did not include cooling costs because we did not get sufficient information on actual costs or usage of cooling facilities. 


\section{INTEREST ON OPERATING CAPITAL}

We calculated interest on operating capital at a nominal rate of 10 percent per year. Interest on operating capital reflects the costs of borrowing money or an opportunity cost for using in-house funds. Interest on operating capital is charged until income is received from the crop at harvest. A nominal interest rate is the current market cost of borrowed funds during the production year.

\section{DISPOSING OF CROP RESIDUE}

After harvest, the field is disced twice to incorporate all crop residues into the soil.

\section{CASH OVERHEAD COSTS}

Land rent. Land rental contracts and charges for agricultural production can range widely by region and also depend on the availability of well water on the property. In Ventura County, if there is a well on the property the landlord often pays for the pump, the permanent parts of the irrigation facilities, and the costs of maintaining the well. The grower generally is responsible for the costs of energy needed to pump the water.

Most of the growers we interviewed rented land with wells that provide a portion of their farms' water requirements. We do not have sufficient data, however, to compare land rent for properties with and without well water. We suggest that growers evaluate the value and costs associated with well water and take this into account when determining an appropriate cost for land rent.

This study assumes an average cash rent of $\$ 1,320$ per acre per year $(\$ 110$ per acre per month). Using a three-month average growth period from land preparation to harvest, the spinach enterprise is charged a rent of $\$ 330$ per acre per crop.

Property taxes. Counties charge a base property tax rate of 1 percent on the assessed value of the property, including equipment, buildings, and improvements. Special assessment districts in some counties charge additional taxes on property. For our study we calculated county taxes at 1 percent of the value of the property.

Insurance. Growers also carry insurance for property protection, which is typically calculated at 0.713 percent of the average value of assets. In addition, a farm of the size specified in this report would carry liability insurance of $\$ 1,040$ per year to cover accidents on the entire farm.

Supervisors, foremen, and management. Interview information indicated that the size of farm we used in this study would require an average of about three employees who are supervisors or foremen. Wages are estimated at $\$ 110$ per acre per year. For three months growth period, the spinach enterprise is charged $\$ 27$ per acre per crop for supervisors and foremen.

Most growers in the survey did not provide management costs, and the wide variations in wages and salaries for professional managers make it difficult to approximate a typical situation. We suggest that, once all production costs have been subtracted from receipts, the residual should be referred to as returns to management.

Office expenses. The office expenses category covers office supplies, telephone service, operating costs for a fax machine, photocopier, and computer, bookkeeping, accounting, legal fees, and so on. Our interview average for office expenses is about $\$ 360$ per acre per year. For the three months of spinach crop production, office expenses are around $\$ 90$ per acre per crop. 


\section{NON-CASH OVERHEAD COSTS}

We calculated the non-cash overhead or ownership costs of assets (including farm equipment and other investments like an irrigation system, buildings, a fuel tank, and pumps) using the capital recovery method. This method helps growers calculate an annual amount of money to charge the enterprise so that the value of assets will be recovered within a specified period of time at a designated rate of interest. The rate of interest used to calculate ownership cost is 7.40 percent: California's long-term average return rate on agricultural production assets from current income. Because farms use a mix of old and new equipment, we evaluated the value of the equipment complement at 60 percent of new prices.

\section{EQUIPMENT OPERATING CASH COSTS}

Equipment operating cash costs for fuel, lubrication, and repairs are calculated using formulas and coefficients developed by the American Society of Agricultural Engineers (ASAE). Repair costs are based on purchase price, annual hours of use, total hours of life, and repair coefficients formulated by the ASAE. Fuel and lubrication costs are also determined by ASAE equations based on machinery horsepower (maximum PTO HP) and type of fuel used. Fuel costs are calculated using average (1996 to 1999 period) on-farm delivery prices of $\$ 0.72$ per gallon for diesel and $\$ 1.20$ per gallon for gasoline. The cost of energy for electric irrigation pumps is $\$ 0.105$ per KW.

\section{LA B O R}

Labor includes owner and hired operator labor with the same wage rate. Hourly labor wages are $\$ 7.50$ per hour for machine operators and $\$ 6.25$ per hour for other, nonmachine workers. These wages are averages based on data from the growers we interviewed. Growers also pay 20 to 34 percent for benefits, which include Workers Compensation, Social Security, Medicare insurance, and other possible benefits. In this study, we assumed an additional 34 percent for benefits, which brings the labor rate to about $\$ 10.00$ per hour for machine operators and $\$ 8.40$ per hour for other or non-machine workers.

We calculated 20 percent additional labor time for machinery operation than the time estimated for the actual operation. This percentage accounts for the setup, moving, maintenance, and repair of equipment.

Table A. Havested acreage, average yield, and average prices for spinach, Ventura County, 1995-1999

\begin{tabular}{lccc}
\hline Year & $\begin{array}{c}\text { Harvested } \\
\text { acreage }\end{array}$ & $\begin{array}{c}\text { Cartons } \\
\text { per acre* }\end{array}$ & $\begin{array}{c}\text { Price per } \\
\text { carton (\$) }\end{array}$ \\
\hline 1995 & 1,317 & 625 & 5.86 \\
1996 & 1,493 & 619 & 6.27 \\
1997 & 1,462 & 563 & 6.37 \\
1998 & 1,273 & 562 & 7.32 \\
1999 & 1,807 & 640 & 6.39 \\
Approximate \\
average 1,470 \\
*One carton equals 20 pounds.
\end{tabular}

*One carton equals 20 pounds.

\section{PRICES AND YIELDS}

Growers did not provide sufficient data on yield or prices, so we used average prices and yields provided by Ventura County Agricultural Commissioner Crop Reports for the 1995 to 1999 period (table A) to estimate gross returns. The county crop reports use free on board (f.o.b.) prices to estimate growers' returns. These prices include harvesting and packing costs, but growers' prices may be different if they incur postharvest costs such as selling and cooling.

\section{SUMMARY OF COSTS}

Our sample estimate of the total cost of spinach production in Ventura County is $\$ 3,604$ per acre (tables 1 and 2 ). Table 1 presents costs by type of activity and table 2 presents costs by type of input. 
The pie graph below shows the breakdown of costs. It consists of about 24 percent for land preparation, planting, and growing costs, 56 percent for harvest and postharvest costs, 14 percent for cash overhead, 1 percent for interest on operating capital, and 5 percent for non-cash overhead costs. Land preparation, planting, and growing costs include fuel, lube, and machinery repairs, as well as materials and labor for all production practices. Harvesting costs in this study include the cost of the carton, picking and packing, loading, and hauling to the nearest cooling facility, and selling. Postharvest cost in this study include two discings. Cash overhead costs include land rent, office expenses, liability insurance, supervisor and foremen wages, property taxes, property insurance, and investment repairs.

Figure 1. Proportion of production costs for spinach, Ventura County, 1999.

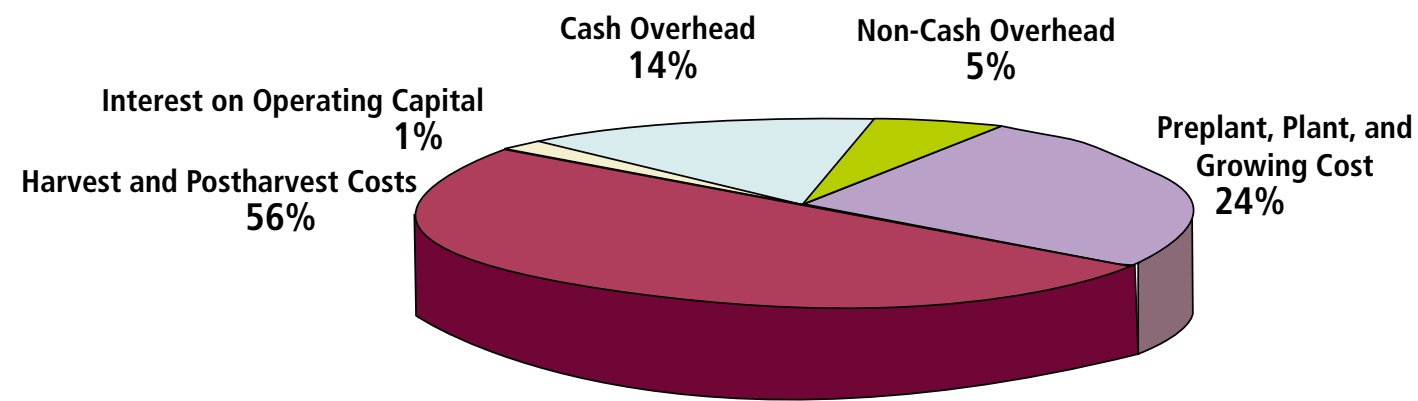

\section{PROFITABILITY ANALYSIS}

We analyzed profitability using breakeven costs per carton and gross and economic margins. Breakeven costs allow growers to compare expected market prices with the unit cost of production.

Gross margin (or returns above cash costs) is what growers often refer to as profit if there is no debt on the farming operation. It approximates the return to management and investment. If you deduct depreciation, it also approximates taxable income.

Economic profit (or returns above total cost including management) is a very useful measure of how attractive the enterprise is for potential investors and entrants into the business. Economic profit can be positive or zero. A zero economic profit should not be alarming if all costs, including the owners' labor and management costs, are included (and assumed paid) in the production cost. In this study we do not include management charges, so the return after all costs are deducted reflects return to management.

Given the assumptions upon which we based this cost study, the breakeven price for the five years county average yield of 600 cartons per acre is estimated at about $\$ 5.72$ per carton to cover all cash costs and $\$ 6.01$ per carton to cover total costs (table 4 part A). On the other hand, the breakeven yield for the county average price of $\$ 6.40$ per carton is about 536 cartons per acre for cash costs and 563 cartons per acre for total costs. Breakeven price is calculated as the cost of production per acre divided by the yield per acre. Break-even yield is calculated as cost of production divided by price per carton.

Gross margin for the county average yield and price is estimated at $\$ 407$ per acre (table 4 part C). This is calculated as gross returns (price times yield) minus cash costs of production. Returns to management for the county average yield and price are estimated at $\$ 236$ per acre (table 4 part $\mathrm{D}$ ). This figure is calculated as gross returns minus total (cash and non-cash) costs of production. 
Crop yield and prices received by growers, however, vary from individual to individual. Selling and cooling costs in particular influence prices depending on whether the costs are incurred by the grower or by the buyer.

We have provided range analyses of price and yield variations on profitability so that each grower can find figures that best match his or her specific situation. The range analyses include break-even prices at various yields as well as gross margins and returns to management at various yield and price combinations. The gross margin and returns to management ranges are analyzed at increments of $\$ 0.10$ per carton for prices and 50 cartons per acre for yield (table 4, parts A through D). 
Table 1. Costs per acre to produce spinach, Ventura County, 1999 (labor rates: $\$ 10.00 / \mathrm{hr}$ for machine labor, $\$ 8.40 / \mathrm{hr}$ for nonmachine labor; interest rate: $10.00 \%)$

\begin{tabular}{|c|c|c|c|c|c|c|c|}
\hline \multirow[b]{2}{*}{ Operation } & \multirow{2}{*}{$\begin{array}{c}\text { Operation } \\
\text { time } \\
\text { (hrs/ac) }\end{array}$} & \multicolumn{5}{|c|}{ Costs per acre (\$) } & \multirow[b]{2}{*}{$\begin{array}{c}\text { Your } \\
\text { cost (\$) }\end{array}$} \\
\hline & & $\begin{array}{l}\text { Labor } \\
\text { cost }\end{array}$ & $\begin{array}{l}\text { Fuel, lube, } \\
\& \text { repairs }\end{array}$ & $\begin{array}{c}\text { Material } \\
\text { cost }\end{array}$ & $\begin{array}{l}\text { Custom/ } \\
\text { rent }\end{array}$ & $\begin{array}{l}\text { Total } \\
\text { cost }\end{array}$ & \\
\hline \multicolumn{8}{|l|}{ Preplant: } \\
\hline Disc $2 x$ & 0.38 & 5 & 5 & 0 & 0 & 9 & \\
\hline Rip 2x & 0.57 & 7 & 1 & 0 & 0 & 8 & \\
\hline Plow & 0.21 & 3 & 3 & 0 & 0 & 6 & \\
\hline Disc $3 x$ & 0.57 & 7 & 8 & 0 & 0 & 15 & \\
\hline Landplane $3 \mathrm{x}$ & 0.55 & 7 & 6 & 0 & 0 & 13 & \\
\hline Chisel & 0.25 & 3 & 4 & 0 & 0 & 7 & \\
\hline Listing \& pre-plant fertilize & 0.33 & 7 & 4 & 66 & 0 & 77 & \\
\hline Shape beds \& roll & 0.23 & 3 & 2 & 0 & 0 & 5 & \\
\hline TOTAL PREPLANT COSTS & 3.09 & 40 & 33 & 66 & 0 & 139 & \\
\hline \multicolumn{8}{|l|}{ Plant: } \\
\hline Seeds (plant \& labor) & 0.22 & 3 & 4 & 258 & 0 & 264 & \\
\hline TOTAL PLANT COSTS & 0.22 & 3 & 4 & 258 & 0 & 264 & \\
\hline \multicolumn{8}{|l|}{ Growing: } \\
\hline Sprinkler setup (machine \& labor) & 0.20 & 15 & 1 & 0 & 0 & 16 & \\
\hline Irrigate 5x (sprinkler) & 2.25 & 19 & 0 & 36 & 0 & 55 & \\
\hline \multicolumn{8}{|l|}{ Fuel/electricity for } \\
\hline irrigation pumps (growing) & 0 & 0 & 0 & 27 & 0 & 27 & \\
\hline Weed management $2 x$ & 10.00 & 84 & 0 & 63 & 0 & 147 & \\
\hline Sprinkler removal (machine \& labor & or) 0.20 & 15 & 1 & 0 & 0 & 16 & \\
\hline Furrow setup (labor) & 0.40 & 3 & 0 & 0 & 0 & 3 & \\
\hline Irrigate 3x (furrow) & 0.90 & 8 & 0 & 41 & 0 & 49 & \\
\hline \multicolumn{8}{|l|}{ Electricity for } \\
\hline irrigation pumps (growing) & 0 & 0 & 0 & 14 & 0 & 14 & \\
\hline Fertilize & 0 & 0 & 0 & 42 & 0 & 42 & \\
\hline Disease management $1 \mathrm{x}$ & 0.21 & 2 & 2 & 34 & 0 & 38 & \\
\hline Pest management $3 \mathrm{x}$ & 0.62 & 7 & 6 & 18 & 0 & 31 & \\
\hline Cultivate $2 x$ & 0.46 & 6 & 5 & 0 & 0 & 10 & \\
\hline Pickup truck & 1.60 & 19 & 8 & 0 & 0 & 27 & \\
\hline TOTAL GROWING COSTS & 16.84 & 178 & 21 & 275 & 0 & 475 & \\
\hline \multicolumn{8}{|l|}{ Harvest \& Sell } \\
\hline Harvest \& sell & 0 & 0 & 0 & 2,010 & 0 & 2,010 & \\
\hline \multicolumn{8}{|l|}{ TOTAL HARVEST } \\
\hline \& SELL COSTS & 0 & 0 & 0 & 2,010 & 0 & 2,021 & \\
\hline
\end{tabular}


Table 1. Continued

\begin{tabular}{|c|c|c|c|c|c|c|c|}
\hline \multirow[b]{2}{*}{ Operation } & \multirow{2}{*}{$\begin{array}{l}\text { Operation } \\
\text { time } \\
\text { (hrs/ac) } \\
\end{array}$} & \multicolumn{5}{|c|}{ Costs per acre (\$) } & \multirow[b]{2}{*}{$\begin{array}{c}\text { Your } \\
\text { cost }(\$)\end{array}$} \\
\hline & & $\begin{array}{c}\text { Labor } \\
\text { cost }\end{array}$ & $\begin{array}{l}\text { Fuel, lube, } \\
\text { \& repairs }\end{array}$ & $\begin{array}{c}\text { Material } \\
\text { cost }\end{array}$ & $\begin{array}{l}\text { Custom/ } \\
\text { rent }\end{array}$ & $\begin{array}{l}\text { Total } \\
\text { cost }\end{array}$ & \\
\hline \multicolumn{8}{|l|}{ Disposing of Crop Residue: } \\
\hline Postharvest disc $2 \times$ & 0.38 & 5 & 5 & 0 & 0 & 9 & \\
\hline \multicolumn{8}{|l|}{ TOTAL DISPOSING OF } \\
\hline CROP RESIDUE COSTS & 0.38 & 5 & 5 & 0 & 0 & 9 & \\
\hline \multicolumn{8}{|l|}{ Interest on operating capital } \\
\hline @ 10.00\% & & & & & & 33 & \\
\hline TOTAL OPERATING COS & ICRE & 225 & 62 & 2,609 & 0 & 2,930 & \\
\hline
\end{tabular}

Cash Overhead:

Land rent

Office expense

Liability insurance

Supervisors \& foreman

Property taxes

Property insurance

Investment repairs

TOTAL CASH OVERHEAD COSTS

TOTAL CASH COSTS/ACRE

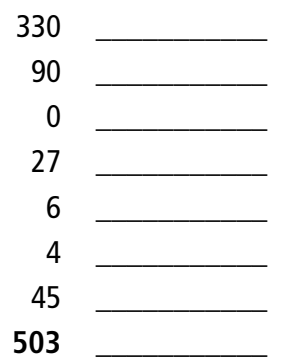

3,433

\begin{tabular}{|c|c|c|c|c|}
\hline & $\begin{array}{c}\text { Costs per } \\
\text { producing } \\
\text { acre }(\$) \\
\end{array}$ & $\begin{array}{c}\text { Annual } \\
\text { cost: } \\
\text { capital } \\
\text { recovery }(\$)\end{array}$ & $\begin{array}{c}\text { Total } \\
\text { cost }(\$)\end{array}$ & $\begin{array}{c}\text { Your } \\
\text { cost (\$) }\end{array}$ \\
\hline \multicolumn{5}{|l|}{ Non-cash Overhead: } \\
\hline \multicolumn{5}{|l|}{ Investment } \\
\hline Shop building & 23 & 3 & 3 & \\
\hline Shop tools & 12 & 1 & 1 & \\
\hline Fuel tanks \& pumps & 15 & 2 & 2 & \\
\hline Irrigation pump & 333 & 46 & 46 & \\
\hline Sprinklers \& pipes & 549 & 76 & 76 & \\
\hline Equipment & 175 & 44 & 44 & \\
\hline TOTAL NON-CASH OVERHEAD COSTS & 1,106 & 171 & 171 & \\
\hline TOTAL COSTS/ACRE & & & 3,604 & \\
\hline
\end{tabular}


Table 2. Costs and returns per acre to produce spinach, Ventura County, 1999 (labor rates: $\$ 10.00 / \mathrm{hr}$ for machine labor, \$8.40/hr for non-machine labor; interest rate: $10.00 \%$ )

\begin{tabular}{|c|c|c|c|c|c|}
\hline & $\begin{array}{l}\text { Quantity } \\
\text { per acre }\end{array}$ & Unit & $\begin{array}{l}\text { Price or } \\
\text { cost per } \\
\text { unit }(\$)\end{array}$ & $\begin{array}{l}\text { Value or } \\
\text { cost per } \\
\text { acre }(\$)\end{array}$ & $\begin{array}{c}\text { Your } \\
\text { cost (\$) }\end{array}$ \\
\hline Gross Returns & 600.00 & carton & 6.40 & 3,840 & \\
\hline \multicolumn{6}{|l|}{ TOTAL GROSS RETURNS } \\
\hline FOR SPINACH & & & & 3,840 & \\
\hline \multicolumn{6}{|l|}{ Operating Costs: } \\
\hline \multicolumn{6}{|l|}{ Fertilize: } \\
\hline 16-20-0 (preplant) & 400.00 & pound & 0.165 & 66 & \\
\hline AN 20 (growing) & 40.00 & gallon & 1.05 & 42 & \\
\hline \multicolumn{6}{|l|}{ Seed: } \\
\hline Spinach seed & 25.00 & pound & 10.32 & 258 & \\
\hline \multicolumn{6}{|l|}{ Water: } \\
\hline Water & 11.25 & acre-inch & 6.83 & 77 & \\
\hline \multicolumn{6}{|l|}{ Fuel (pump): } \\
\hline Booster pump fuel & 21.00 & gallon & 0.72 & 15 & \\
\hline \multicolumn{6}{|l|}{ Electricity (pump): } \\
\hline Low-pressure pump & 252.00 & KW & 0.105 & 26 & \\
\hline Weed management & 1.00 & acre & 63.00 & 63 & \\
\hline Disease management & 1.00 & acre & 34.00 & 34 & \\
\hline Pest management & 1.00 & acre & 18.00 & 18 & \\
\hline \multicolumn{6}{|l|}{ Harvest \& sell: } \\
\hline Cartons & 600.00 & carton & 1.20 & 720 & \\
\hline Pick \& pack & 600.00 & carton & 1.00 & 600 & \\
\hline Load \& haul & 600.00 & carton & 0.65 & 390 & \\
\hline Selling & 600.00 & carton & 0.50 & 300 & \\
\hline Labor (machine) & 8.38 & hour & 10.00 & 84 & \\
\hline Labor (non-machine) & 16.87 & hour & 8.40 & 142 & \\
\hline \multicolumn{6}{|l|}{ Fuel } \\
\hline Gasoline & 4.00 & gallon & 1.20 & 5 & \\
\hline Diesel & 36.90 & gallon & 0.72 & 27 & \\
\hline Lube & & & & 5 & \\
\hline Machinery repair & & & & 26 & \\
\hline \multicolumn{6}{|l|}{ Interest on operating } \\
\hline capital @ 10.00\% & & & & 33 & \\
\hline \multicolumn{3}{|c|}{ TOTAL OPERATING COSTS/ACRE } & & 2,930 & \\
\hline \multicolumn{3}{|c|}{ NET RETURNS ABOVE OPERATING COSTS } & & 910 & \\
\hline
\end{tabular}


Table 2. Continued

\begin{tabular}{|c|c|c|c|c|}
\hline $\begin{array}{l}\text { Quantity } \\
\text { per acre }\end{array}$ & Unit & $\begin{array}{l}\text { Price or } \\
\text { cost per } \\
\text { unit (\$) }\end{array}$ & $\begin{array}{l}\text { Value or } \\
\text { cost per } \\
\text { acre (\$) }\end{array}$ & $\begin{array}{c}\text { Your } \\
\text { cost (\$) }\end{array}$ \\
\hline \multicolumn{5}{|l|}{ Cash Overhead Costs: } \\
\hline Land rent & & & 330 & \\
\hline Office expense & & & 90 & \\
\hline Liability insurance & & & 0 & \\
\hline Supervisors \& foreman & & & 27 & \\
\hline Property taxes & & & 6 & \\
\hline Property insurance & & & 4 & \\
\hline Investment repairs & & & 45 & \\
\hline TOTAL CASH OVERHEAD COSTS/ACRE & & & 503 & \\
\hline TOTAL CASH COSTS/ACRE & & & 3,433 & \\
\hline \multicolumn{5}{|l|}{ Non-cash Overhead Costs (Capital Recovery): } \\
\hline Shop building & & & 3 & \\
\hline Shop tools & & & 1 & \\
\hline Fuel tanks \& pumps & & & 2 & \\
\hline Irrigation pump & & & 46 & \\
\hline Sprinklers \& pipes & & & 76 & \\
\hline Equipment & & & 44 & \\
\hline TOTAL NON-CASH OVERHEAD COSTS/ACRE & & & 171 & \\
\hline TOTAL COSTS/ACRE & & & 3,604 & \\
\hline NET RETURNS ABOVE TOTAL COSTS & & & 236 & \\
\hline
\end{tabular}


Table 3. Monthly cash costs per acre to produce spinach, Ventura County, 1999

\begin{tabular}{|c|c|c|c|c|}
\hline \multirow[b]{2}{*}{ Operation } & \multicolumn{4}{|c|}{ Costs per acre (\$) } \\
\hline & Month 1 & Month 2 & Month 3 & Total \\
\hline \multicolumn{5}{|l|}{ Preplant: } \\
\hline Disc $2 x$ & 9 & & & 9 \\
\hline $\operatorname{Rip} 2 \times$ & 8 & & & 8 \\
\hline Plow & 6 & & & 6 \\
\hline Disc $3 x$ & 15 & & & 15 \\
\hline Landplane $3 \times$ & 13 & & & 13 \\
\hline Chisel & 7 & & & 7 \\
\hline Listing \& preplant fertilize & 77 & & & 77 \\
\hline Shape beds \& roll & 5 & & & 5 \\
\hline TOTAL PREPLANT COSTS & 139 & & & 139 \\
\hline \multicolumn{5}{|l|}{ Plant: } \\
\hline Seeds (plant \& labor) & 264 & & & 264 \\
\hline TOTAL PLANT COSTS & 264 & & & 264 \\
\hline \multicolumn{5}{|l|}{ Growing: } \\
\hline Sprinkler setup (machine \& labor) & & 16 & & 16 \\
\hline Irrigate 5x (sprinkler) & & 55 & & 55 \\
\hline \multicolumn{5}{|l|}{ Fuel/electricity for } \\
\hline irrigation pumps (growing) & & 27 & & 27 \\
\hline Weed management & & 63 & 84 & 147 \\
\hline Sprinkler removal (machine \& labor) & & 16 & & 16 \\
\hline Furrow setup (labor) & & 3 & & 3 \\
\hline Irrigate $3 x$ (furrow) & & 9 & 39 & 49 \\
\hline \multicolumn{5}{|l|}{ Electricity for } \\
\hline irrigation pumps (growing) & & 2 & 12 & 14 \\
\hline Fertilize & & 10 & 31 & 42 \\
\hline Disease management $1 \mathrm{x}$ & & & 38 & 38 \\
\hline Pest management $3 x$ & & 13 & 18 & 31 \\
\hline Cultivate $2 \mathrm{x}$ & & 5 & 5 & 10 \\
\hline Pickup truck & 9 & 9 & 9 & 27 \\
\hline TOTAL GROWING COSTS & 9 & 230 & 236 & 475 \\
\hline \multicolumn{5}{|l|}{669} \\
\hline \multicolumn{5}{|l|}{ Harvest \& Sell: } \\
\hline Harvest \& sell & & & 2,010 & 2,010 \\
\hline \multicolumn{5}{|l|}{ TOTAL HARVEST } \\
\hline \& SELL COSTS & & & 2,010 & 2,010 \\
\hline \multicolumn{5}{|l|}{ Disposing of Crop Residue: } \\
\hline Postharvest disc $2 \times$ & & & 9 & 9 \\
\hline \multicolumn{5}{|l|}{ TOTAL DISPOSING OF } \\
\hline CROP RESIDUE COSTS & & & 9 & 9 \\
\hline \multicolumn{5}{|l|}{ Interest on operating capital } \\
\hline @ 10.00\% & 3 & 5 & 24 & 33 \\
\hline TOTAL OPERATING COSTS/ACRE & 416 & 235 & 2,280 & 2,930 \\
\hline
\end{tabular}


Table 3. Continued

\begin{tabular}{lccrr}
\hline & \multicolumn{4}{c}{ Costs per acre (\$) } \\
\cline { 2 - 5 } Operation & Month 1 & Month 2 & Month 3 & Total \\
\hline Cash Overhead: & 110 & 110 & 110 & 330 \\
Land rent & 30 & 30 & 30 & 90 \\
Office expense & 0 & 0 & 0 & 0 \\
Liability insurance & 9 & 9 & 9 & 6 \\
Supervisors \& foreman & 3 & & 3 & 4 \\
Property taxes & 2 & 15 & 15 & 45 \\
Property insurance & 15 & 164 & 169 & 503 \\
Investment repairs & 169 & & 2,449 & 3,433 \\
$\quad$ TOTAL CASH OVERHEAD COSTS & 585 & 399 & & \\
TOTAL CASH COSTS/ACRE & & & & \\
\end{tabular}


Table 4. Range analyses of spinach production costs and returns, Ventura County, 1999

\begin{tabular}{|c|c|c|c|c|c|c|c|}
\hline & \multicolumn{7}{|c|}{ Costs per acre (\$) for various cartons-per-acre yields } \\
\hline & $\overline{450}$ & 500 & 550 & 600 & 650 & 700 & 750 \\
\hline \multicolumn{8}{|c|}{ Part A. Costs per Acre and per Carton at Varying Yields } \\
\hline \multicolumn{8}{|l|}{ Operating costs/acre: } \\
\hline Preplant cost & 139 & 139 & 139 & 139 & 139 & 139 & 139 \\
\hline Plant cost & 264 & 264 & 264 & 264 & 264 & 264 & 264 \\
\hline Growing cost & 475 & 475 & 475 & 475 & 475 & 475 & 475 \\
\hline Harvest \& sell cost & 1,507 & 1,675 & 1,843 & 2,018 & 2,178 & 2,345 & 2,513 \\
\hline Disposing of crop residue cost & 9 & 9 & 9 & 9 & 9 & 9 & 9 \\
\hline Interest on operating capital & 29 & 30 & 31 & 33 & 34 & 36 & 37 \\
\hline TOTAL OPERATING COSTS/ACRE & 2,423 & 2,592 & 2,761 & 2,930 & 3,099 & 3,268 & 3,437 \\
\hline TOTAL OPERATING COSTS/CARTO & N 5.39 & 5.18 & 5.02 & 4.88 & 4.77 & 4.67 & 4.58 \\
\hline CASH OVERHEAD COSTSIACRE & 503 & 503 & 503 & 503 & 503 & 503 & 503 \\
\hline TOTAL CASH COSTSIACRE & 2,926 & 3,095 & 3,264 & 3,433 & 3,601 & 3,770 & 3,939 \\
\hline TOTAL CASH COSTS/CARTON & 6.50 & 6.19 & 5.93 & 5.72 & 5.54 & 5.39 & 5.25 \\
\hline \multicolumn{8}{|l|}{ NON-CASH OVERHEAD } \\
\hline COSTSIACRE & 171 & 171 & 171 & 171 & 171 & 171 & 171 \\
\hline TOTAL COSTS/ACRE & 3,097 & 3,266 & 3,435 & 3,604 & 3,773 & 3,942 & 4,111 \\
\hline TOTAL COSTS/CARTON & 6.88 & 6.53 & 6.25 & 6.01 & 5.80 & 5.63 & 5.48 \\
\hline \multicolumn{8}{|c|}{ Part B. Returns per Acre above Operating Costs } \\
\hline \multicolumn{8}{|l|}{ Price (\$/carton): } \\
\hline$\$ 6.10$ & 322 & 458 & 594 & 730 & 866 & 1,002 & 1,138 \\
\hline$\$ 6.20$ & 367 & 508 & 649 & 790 & 931 & 1,072 & 1,213 \\
\hline$\$ 6.30$ & 412 & 558 & 704 & 850 & 996 & 1,142 & 1,288 \\
\hline$\$ 6.40$ & 457 & 608 & 759 & 910 & 1,061 & 1,212 & 1,363 \\
\hline$\$ 6.50$ & 502 & 658 & 814 & 970 & 1,126 & 1,282 & 1,438 \\
\hline$\$ 6.60$ & 547 & 708 & 869 & 1,030 & 1,191 & 1,352 & 1,513 \\
\hline$\$ 6.70$ & 592 & 758 & 924 & 1,090 & 1,256 & 1,422 & 1,588 \\
\hline
\end{tabular}

Part C. Returns per Acre above All Cash Costs (gross margin)

Price (\$/carton):

$\begin{array}{lrrrrrrr}\$ 6.10 & -181 & -45 & 91 & 227 & 364 & 500 & 636 \\ \$ 6.20 & -136 & 5 & 146 & 287 & 429 & 570 & 711 \\ \$ 6.30 & -91 & 55 & 201 & 347 & 494 & 640 & 786 \\ \$ 6.40 & -46 & 105 & 256 & 407 & 559 & 710 & 861 \\ \$ 6.50 & -1 & 155 & 311 & 467 & 624 & 780 & 936 \\ \$ 6.60 & 44 & 205 & 366 & 527 & 689 & 850 & 1,011 \\ \$ 6.70 & 89 & 255 & 421 & 587 & 754 & 920 & 1,086\end{array}$

Part D. Returns per Acre above Total Costs (returns to management)

Price (\$/carton):

$\begin{array}{lrrrrrrr}\$ 6.10 & -352 & -216 & -80 & 56 & 192 & 328 & 464 \\ \$ 6.20 & -307 & -166 & -25 & 116 & 257 & 398 & 539 \\ \$ 6.30 & -262 & -116 & 30 & 176 & 322 & 468 & 614 \\ \$ 6.40 & -217 & -66 & 85 & 236 & 387 & 538 & 689 \\ \$ 6.50 & -172 & -16 & 140 & 296 & 452 & 608 & 764 \\ \$ 6.60 & -127 & 34 & 195 & 356 & 517 & 678 & 839 \\ \$ 6.70 & -82 & 84 & 250 & 416 & 582 & 748 & 914\end{array}$


Table 5. Farm equipment and investment values and annual costs based on 2,600 annual farmed acres, Ventura County, 1999

\begin{tabular}{|c|c|c|c|c|c|c|c|}
\hline \multirow[b]{3}{*}{ Equipment } & \multirow{3}{*}{$\begin{array}{c}\text { Value: } \\
1999 \\
\text { price (\$) }\end{array}$} & \multirow[b]{3}{*}{ Life (yrs) } & \multirow{3}{*}{$\begin{array}{c}\text { Salvage } \\
\text { value } \\
(\$)\end{array}$} & \multicolumn{4}{|c|}{ Costs } \\
\hline & & & & \multirow{2}{*}{$\begin{array}{c}\text { Capital } \\
\text { recovery } \\
(\$)\end{array}$} & \multicolumn{2}{|c|}{$\begin{array}{l}\text { Annual cash } \\
\text { overhead (\$) }\end{array}$} & \multirow{2}{*}{$\begin{array}{c}\text { Total } \\
\text { annual } \\
\text { costs }(\$)\end{array}$} \\
\hline & & & & & Insurance & Taxes & \\
\hline 120 HP Tractor 4WD (\#1) & 75,180 & 6 & 7,518 & 14,927 & 295 & 413 & 15,636 \\
\hline 120 HP Tractor 4WD (\#2) & 75,180 & 5 & 7,518 & 17,236 & 295 & 413 & 17,944 \\
\hline 120 HP Tractor 4WD (\#3) & 75,180 & 6 & 7,518 & 14,927 & 295 & 413 & 15,636 \\
\hline 200 HP 4WD Tractor & 135,500 & 6 & 13,550 & 26,904 & 531 & 745 & 28,181 \\
\hline 45 HP 2WD Tractor & 23,030 & 10 & 2,303 & 3,176 & 90 & 127 & 3,393 \\
\hline Bed shaper & 8,900 & 3 & 890 & 3,140 & 35 & 49 & 3,224 \\
\hline Chisel - 14' (\#1) & 2,270 & 3 & 227 & 801 & 9 & 12 & 822 \\
\hline Chisel - 14' (\#2) & 2,270 & 3 & 227 & 801 & 9 & 12 & 822 \\
\hline Cultivator - 4-row 40" (\#1) & 7,130 & 3 & 713 & 2,516 & 28 & 39 & 2,583 \\
\hline Cultivator - 4-row 40" (\#2) & 7,130 & 3 & 713 & 2,516 & 28 & 39 & 2,583 \\
\hline Disc - 21' (\#1) & 16,510 & 5 & 1,651 & 3,785 & 65 & 91 & 3,941 \\
\hline Disc - 21' (\#2) & 16,510 & 5 & 1,651 & 3,785 & 65 & 91 & 3,941 \\
\hline Disc - 21' (\#3) & 16,510 & 5 & 1,651 & 3,785 & 65 & 91 & 3,941 \\
\hline Disc - 21' (\#4) & 16,510 & 5 & 1,651 & 3,785 & 65 & 91 & 3,941 \\
\hline Disc - 21' (\#5) & 16,510 & 5 & 1,651 & 3,785 & 65 & 91 & 3,941 \\
\hline Disc - 21' (\#6) & 16,510 & 5 & 1,651 & 3,785 & 65 & 91 & 3,941 \\
\hline Disc - 21' (\#7) & 16,510 & 5 & 1,651 & 3,785 & 65 & 91 & 3,941 \\
\hline Lister (\#1) & 6,000 & 4 & 600 & 1,653 & 24 & 33 & 1,710 \\
\hline Lister (\#2) & 6,000 & 4 & 600 & 1,653 & 24 & 33 & 1,710 \\
\hline Pickup truck 1/2 ton (\#1) & 17,160 & 2 & 1,716 & 8,716 & 67 & 94 & 8,878 \\
\hline Pickup truck 1/2 ton (\#2) & 17,160 & 2 & 1,716 & 8,716 & 67 & 94 & 8,878 \\
\hline Pickup truck 1/2 ton (\#3) & 17,160 & 2 & 1,716 & 8,716 & 67 & 94 & 8,878 \\
\hline Pickup truck 1/2 ton (\#4) & 17,160 & 2 & 1,716 & 8,716 & 67 & 94 & 8,878 \\
\hline Pickup truck 1/2 ton (\#5) & 17,160 & 2 & 1,716 & 8,716 & 67 & 94 & 8,878 \\
\hline Planter - 6-row & 8,900 & 5 & 890 & 2,040 & 35 & 49 & 2,124 \\
\hline Plow - 6-bottom & 12,000 & 3 & 180 & 4,550 & 43 & 61 & 4,655 \\
\hline Sprayer 600 gallon (\#1) & 100,000 & 5 & 10,000 & 22,926 & 392 & 550 & 23,868 \\
\hline Sprayer 600 gallon (\#2) & 100,000 & 5 & 10,000 & 22,926 & 392 & 550 & 23,868 \\
\hline Subsoiler - 12' (\#1) & 6,490 & 2 & 649 & 3,297 & 25 & 36 & 3,358 \\
\hline Subsoiler - 12' (\#2) & 6,490 & 2 & 649 & 3,297 & 25 & 36 & 3,358 \\
\hline Trailer & 2,000 & 2 & 200 & 1,016 & 8 & 11 & 1,035 \\
\hline Triplane - 14' (\#1) & 18,230 & 5 & 1,823 & 4,179 & 71 & 100 & 4,351 \\
\hline Triplane - 14' (\#2) & 18,230 & 5 & 1,823 & 4,179 & 71 & 100 & 4,351 \\
\hline Triplane - 14' (\#3) & 18,230 & 5 & 1,823 & 4,179 & 71 & 100 & 4,351 \\
\hline TOTAL EQUIPMENT & 915,710 & & 90,551 & 232,916 & 3,587 & 5,031 & 241,535 \\
\hline $60 \%$ OF NEW COST* & 549,426 & & 54,331 & 139,750 & 2,152 & 3,019 & 144,921 \\
\hline
\end{tabular}


Table 5. Continued

\begin{tabular}{|c|c|c|c|c|c|c|c|c|}
\hline \multirow[b]{3}{*}{ Investment } & \multirow{3}{*}{$\begin{array}{c}\text { Value: } \\
1999 \\
\text { price (\$) }\end{array}$} & \multirow[b]{3}{*}{ Life (yrs) } & \multirow{3}{*}{$\begin{array}{c}\text { Salvage } \\
\text { value } \\
(\$)\end{array}$} & \multicolumn{5}{|c|}{ Costs } \\
\hline & & & & \multirow{2}{*}{$\begin{array}{c}\text { Capital } \\
\text { recovery } \\
(\$)\end{array}$} & \multicolumn{3}{|c|}{$\begin{array}{l}\text { Annual cash } \\
\text { overhead (\$) }\end{array}$} & \multirow{2}{*}{$\begin{array}{c}\text { Total } \\
\text { annual } \\
\text { costs }(\$\end{array}$} \\
\hline & & & & & Insurance & Taxes & Repairs & \\
\hline Fuel tanks \& pumps & 38,100 & 15 & 3,810 & 4,142 & 149 & 210 & 1,828 & 6,329 \\
\hline Irrigation pump & 866,666 & 10 & 86,667 & 119,529 & 3,399 & 4,767 & 41,599 & 169,293 \\
\hline Shop building & 60,000 & 15 & 6,000 & 6,524 & 235 & 330 & 2,880 & 9,969 \\
\hline Shop tools & 30,000 & 15 & 3,000 & 3,262 & 118 & 165 & 1,440 & 4,984 \\
\hline Sprinklers \& pipes & $1,427,530$ & 10 & 142,753 & 196,883 & 5,598 & 7,851 & 68,521 & 278,853 \\
\hline TOTAL INVESTMENT & $2,422,296$ & & 242,230 & 330,340 & 9,499 & 13,323 & 116,268 & 469,429 \\
\hline Business Overhead & & & \multicolumn{2}{|c|}{$\begin{array}{l}\text { Enterprise/ } \\
\text { farm size }\end{array}$} & Unit & $\begin{array}{c}\text { Price per } \\
\text { unit (\$) }\end{array}$ & \multicolumn{2}{|c|}{$\begin{array}{l}\text { Total } \\
\text { cost }(\$)\end{array}$} \\
\hline Land rent & & & \multicolumn{2}{|c|}{2,600} & acre & 330 & \multicolumn{2}{|c|}{858,000} \\
\hline Liability insurance & & & \multicolumn{2}{|c|}{2,600} & acre & 0.40 & \multicolumn{2}{|c|}{1,040} \\
\hline Office expense & & & \multicolumn{2}{|c|}{2,600} & acre & 90 & \multicolumn{2}{|c|}{234,000} \\
\hline Supervisors \& foreman & & & \multicolumn{2}{|c|}{2,600} & acre & 27 & \multicolumn{2}{|c|}{70,200} \\
\hline
\end{tabular}


Table 6. Farm equipment actual hours of use and hourly costs based on 2,600 annual farmed acres, Ventura County, 1999

\begin{tabular}{|c|c|c|c|c|c|c|c|}
\hline \multirow[b]{4}{*}{ Description } & \multirow{4}{*}{$\begin{array}{l}\text { Actual } \\
\text { hours } \\
\text { of use }\end{array}$} & \multicolumn{6}{|c|}{ Costs per hour (\$) } \\
\hline & & \multirow{3}{*}{$\begin{array}{l}\text { Capital } \\
\text { recovery }\end{array}$} & \multirow{2}{*}{\multicolumn{2}{|c|}{ Cash overhead }} & \multicolumn{2}{|c|}{ Operating } & \multirow{3}{*}{$\begin{array}{c}\text { Total } \\
\text { costs } \\
\text { per hour }\end{array}$} \\
\hline & & & & & & Fuel & \\
\hline & & & Insurance & $\overline{\text { Taxes }}$ & Repairs & \& lube & \\
\hline 120 HP Tractor 4WD (\#1) & 2,500 & 3.58 & 0.07 & 0.10 & 1.89 & 5.77 & 11.41 \\
\hline 120 HP Tractor 4WD (\#2) & 3,000 & 3.45 & 0.06 & 0.08 & 1.91 & 5.77 & 11.27 \\
\hline 120 HP Tractor 4WD (\#3) & 2,500 & 3.58 & 0.07 & 0.10 & 1.89 & 5.77 & 11.41 \\
\hline 200 HP 4WD Tractor & 2,600 & 6.21 & 0.12 & 0.17 & 3.54 & 9.61 & 19.65 \\
\hline 45 HP 2WD Tractor & 1,200 & 1.59 & 0.05 & 0.06 & 1.03 & 1.83 & 4.55 \\
\hline Bed shaper & 670 & 2.81 & 0.03 & 0.04 & 1.53 & 0 & 4.42 \\
\hline Chisel - 14' (\#1) & 740 & 0.65 & 0.01 & 0.01 & 0.44 & 0 & 1.11 \\
\hline Chisel - 14' (\#2) & 740 & 0.65 & 0.01 & 0.01 & 0.44 & 0 & 1.11 \\
\hline Cultivator - 4-row 40" (\#1) & 740 & 2.04 & 0.02 & 0.03 & 1.39 & 0 & 3.49 \\
\hline Cultivator - 4-row 40" (\#2) & 740 & 2.04 & 0.02 & 0.03 & 1.39 & 0 & 3.49 \\
\hline Disc $-21^{\prime}(\# 1)$ & 500 & 4.54 & 0.08 & 0.11 & 3.65 & 0 & 8.38 \\
\hline Disc - 21' (\#2) & 500 & 4.54 & 0.08 & 0.11 & 3.65 & 0 & 8.38 \\
\hline Disc - 21' (\#3) & 500 & 4.54 & 0.08 & 0.11 & 3.65 & 0 & 8.38 \\
\hline Disc - 21' (\#4) & 500 & 4.54 & 0.08 & 0.11 & 3.65 & 0 & 8.38 \\
\hline Disc - 21' (\#5) & 500 & 4.54 & 0.08 & 0.11 & 3.65 & 0 & 8.38 \\
\hline Disc - 21' (\#6) & 500 & 4.54 & 0.08 & 0.11 & 3.65 & 0 & 8.38 \\
\hline Disc - 21' (\#7) & 500 & 4.54 & 0.08 & 0.11 & 3.65 & 0 & 8.38 \\
\hline Lister (\#1) & 500 & 1.98 & 0.03 & 0.04 & 2.60 & 0 & 4.65 \\
\hline Lister (\#2) & 500 & 1.98 & 0.03 & 0.04 & 2.60 & 0 & 4.65 \\
\hline Pickup truck 1/2 ton (\#1) & 1,000 & 5.23 & 0.04 & 0.06 & 1.29 & 3.45 & 10.06 \\
\hline Pickup truck 1/2 ton (\#2) & 1,000 & 5.23 & 0.04 & 0.06 & 1.29 & 3.45 & 10.06 \\
\hline Pickup truck 1/2 ton (\#3) & 1,000 & 5.23 & 0.04 & 0.06 & 1.29 & 3.45 & 10.06 \\
\hline Pickup truck 1/2 ton (\#4) & 1,000 & 5.23 & 0.04 & 0.06 & 1.29 & 3.45 & 10.06 \\
\hline Pickup truck 1/2 ton (\#5) & 1,000 & 5.23 & 0.04 & 0.06 & 1.29 & 3.45 & 10.06 \\
\hline Planter - 6-row & 500 & 2.45 & 0.04 & 0.06 & 1.97 & 0 & 4.52 \\
\hline Plow - 6-bottom & 610 & 4.48 & 0.04 & 0.06 & 1.82 & 0 & 6.40 \\
\hline Sprayer 600 gallon (\#1) & 2,000 & 6.88 & 0.12 & 0.17 & 4.80 & 3.31 & 15.27 \\
\hline Sprayer 600 gallon (\#2) & 2,000 & 6.88 & 0.12 & 0.17 & 4.80 & 3.31 & 15.27 \\
\hline Subsoiler - 12' (\#1) & 840 & 2.35 & 0.02 & 0.03 & 1.28 & 0 & 3.68 \\
\hline Subsoiler - 12' (\#2) & 840 & 2.35 & 0.02 & 0.03 & 1.28 & 0 & 3.68 \\
\hline Trailer & 1,000 & 0.61 & 0.01 & 0.01 & 0.35 & 0 & 0.97 \\
\hline Triplane - 14' (\#1) & 540 & 4.64 & 0.08 & 0.11 & 2.74 & 0 & 7.57 \\
\hline Triplane - 14' (\#2) & 540 & 4.64 & 0.08 & 0.11 & 2.74 & 0 & 7.57 \\
\hline Triplane - 14' (\#3) & 540 & 4.64 & 0.08 & 0.11 & 2.74 & 0 & 7.57 \\
\hline
\end{tabular}




\section{REFERENCES}

American Society of Agricultural Engineers. 1992. American Society of Agricultural Engineers Standards Yearbook. St. Joseph, MI: ASAE.

Boelje, M. D., and V. R. Eidman. 1984. Farm management. New York: John Wiley and Sons.

Brendler, R. A. 1990. Costs and practices in Ventura County for lima beans and vegetables. Ventura: University of California Cooperative Extension, Ventura County. June, 1990.

LeStrange, M., S. Koike, J. Vakebcua, and W. Chaney. 1996. Spinach production in California. Oakland: University of California Division of Agriculture and Natural Resources. Publication 7212.

Ventura County Agricultural Commissioner. 1998. Ventura County annual crop report. Santa Paula, CA: County Agricultural Commissioner. 


\section{FOR MORE INFORMATION}

You'll find detailed information on many aspects of vegetable production in these titles and in other publications, slide sets, and videos from UC ANR:

Commercial Cooling of Fruits, Vegetables, and Flowers, publication 21567

Commercial Greenhouse Vegetable Handbook, publication 21575

Specialty and Minor Crops Handbook, publication 3346

To order these products, visit our online catalog at http://anrcatalog.ucdavis.edu. You can also place orders by mail, phone, or fax, or request a printed catalog of publications, slide sets, and videos from

University of California

Agriculture and Natural Resources

Communication Services

6701 San Pablo Avenue, 2nd Floor

Oakland, CA 94608-1239

Telephone: (800) 994-8849 or (510) 642-2431, FAX: (510) 643-5470

E-mail inquiries: danrcs@ucdavis.edu

An electronic version of this publication is available on the ANR Communication Services website at http://anrcatalog.ucdavis.edu.

\section{Publication 8032}

C2001 by the Regents of the University of California, Division of Agriculture and Natural Resources. All rights reserved.

To simplify information, trade names of some products have been used in this report. No endorsement of named products is intended, nor is criticism implied of similar products that are not mentioned.

The University of California prohibits discrimination against or harassment of any person employed by or seeking employment with the University on the basis of race, color, national origin, religion, sex, physical or mental disability, medical condition (cancer-related or genetic characteristics), ancestry, marital status, age, sexual orientation, citizenship, or status as a covered veteran (special disabled veteran, Vietnam-era veteran or any other veteran who served on active duty during a war or in a campaign or expedition for which a campaign badge has been authorized). University Policy is intended to be consistent with the provisions of applicable State and Federal laws.

Inquiries regarding the University's nondiscrimination policies may be directed to the Affirmative Action/Staff Personnel Services Director, University of California, Agriculture and Natural Resources, 300 Lakeside Drive, 6th floor, Oakland, CA 94612-3550; (510) 987-0096. For a free catalog of other publications, telephone (800) 994-8849.

pr-09/01-WJC/VFG

ISBN 978-1-60107-210-8

This publication has been anonymously peer reviewed for technical accuracy by University of California scientists and other qualified professionals. This review process was managed by the ANR Associate Editor for Vegetable Crops 